\title{
SYEKH ABDUL HALIM HASAN, 1901-1969: Akar Tradisi Intelektual di Sumatera Timur Awal Abad XX
}

\author{
Zaini Dahlan \\ Universitas Islam Negeri Sumatera Utara Medan \\ J1. Williem Iskandar Pasar V Medan Estate, Medan, Sumatera Utara, 20371 \\ e-mail: zainidahlan@uinsu.ac.id
}

\begin{abstract}
Syekh Abdul Halim Hasan, 1901-1969: The Roots of Intellectual Tradition of East Sumatra in Early 20th Centuries. This study examines the biography and intellectual work of Syekh Abdul Halim Hasan in East Sumatra. The continuation of intellectual traditions in East Sumatra is influenced, among others, by the emergence of scholars in the region. Some of these scholars were local Malays; but a few of them were from Mandailing ethnic who had migrated from South Tapanuli. This study examines the role of Syekh Abdul Halim Hasan, a migrating scholar from Mandailing, in developing Islamic intellectual traditions in East Sumatra. Using a sociologicalhistorical approach, this study proposes the findings that Syekh Abdul Halim Hasan had indeed contributed significantly in strengthening Islamic intellectual traditions of the region. He authored academic works in various fields of Islam, trained younger talented scholars, and also involved in independence struggle in his homeland.
\end{abstract}

Keywords: Mandailingnese, Malay, East Sumatra, Abdul Halim Hasan 


\section{Pendahuluan}

Pendidikan Islam di Indonesia sudah berlangsung sejak masuknya Islam ke Indonesia. ${ }^{1}$ Pada tahap awal, pendidikan Islam dimulai dari kontak-kontak pribadi maupun kolektif antara mubalig(pendidik) dengan peserta didiknya. ${ }^{2}$ Setelah komunitas Muslim terbentuk di suatu daerah tertentu, mereka kemudian membangun tempat ibadah yaitu masjid, langgar atau musala. Setelah penyebaran dan perkembangan agama Islam telah membaur dalam kehidupan masyarakat, komunitas Muslim menjadikan masjid dan langgar selain sebagai tempat beribadah, juga menjadi tempat proses belajar mengajar. Hal seperti ini juga terjadi ketika zaman Nabi Muhammad SAW. sebagai tempat proses belajar mengajar. ${ }^{3}$ Pendidikan Islam pada tahap awal itu berlangsung secara informal. Tidak ada jadwal, materi dan tempat yang khusus. Kontak-kontak awal itu tidak terprogram secara rigit dan ketat. Jadi, hal itu belum melembaga sebagai suatu lembaga tertentu. Di sini, pihak yang paling berperan adalah mubalig. ${ }^{4}$

Dalam konteks ini, banyak sekali tokoh di dunia Islamtidak terkecuali tokoh Islam yang berasal dari Indonesia-yang menyebarkan Islam ke seluruh dunia dengan membangun sebuah madrasah dan menjadi benteng tradisi keulamaan dan intelektual Islam. Misalnya Nizhâm al-Mulk (w. 485/1092), salah seorang wazir Dinasti Saljuk sejak tahun 456/1064 yang telah membangun sebuah lembaga pendidikan Islam yang pada saat ini dikenal luas oleh masyarakat Islam, yaitu Madrasah Nizhamiyah. ${ }^{5}$ Dalam konteks Indonesia, Maulana Malik Ibrahim dipandang sebagai orang yang pertama mendirikan pesantren. ${ }^{6}$ Selanjutnya, tokoh Islam di kerajaan Aceh, yakni Hamzah Fansuri, seorang pujangga dan guru agama yang terkenal dengan ajaran tasawuf yang beraliran wujûdiyah. ${ }^{7}$ Ulama penting lainnya adalah Syamsuddin al-Sumathrani (w. 1039/1630) atau lebih dikenal dengan Syamsuddin Pasai. Ulama 
dan pujangga lain yang pernah datang ke Kerajaan Aceh ialah Syekh Nûr al-Dîn al-Rânirî (w. 1068/1658). ${ }^{8}$

Pada masa kolonial Belanda, ada banyak ulama yang berjasa dalam menggagas pendirian madrasah di Indonesia. ${ }^{9} \mathrm{Di}$ antara mereka adalah Syekh Abdullah Ahmad, pendiri Madrasah Adabiyah di Padang tahun 1909. ${ }^{10}$ Syekh M. Thaib Umar, pendiri Madrasah School di Batu Sangkar tahun $1910 .{ }^{11}$ Tiga tahun kemudian madrasah ini ditutup dan baru pada tahun 1918 dibuka kembali oleh Mahmud Yunus dan pada tahun 1923 madrasah ini berganti nama dengan Diniyah School. Pada tahun yang sama Rengkayo Rahmah El Yunusiyah mendirikan Madrasah Diniyah Putri Padang Panjang. ${ }^{12}$ Para ulama memang cukup kontributif dalam pengembangan ajaran Islam di Sumatera Barat. Memang, kajian selama ini lebih banyak terfokus pada peran ulama di Jawa, dan untuk pulau Sumatera terfokus pada wilayah Aceh dan Sumatera Barat. Kajian tentang ulama yang berkontribusi bagi pengembangan Islam, khususnya tradisi intelektual Islam di Sumatera Timur cukup langka.

Dalam konteks ini, selain Medan, kota Binjai yang dahulu merupakan bagian dari Kesultanan Langkat Sumatera Timur, memiliki beberapa ulama yang menarik dikaji dan dikenalkan kepada publik. Satu di antara mereka adalah Syekh Abdul Halim Hasan. Ia tidak saja berdedikasi dalam bidang keagamaan, tetapi juga berkontribusi bagi kemerdekaan Indonesia. Karya-karyanya diyakini memiliki dampak bagi kelestarian ajaran Islam dan kemajuan tradisi intelektual Islam khususnya di Sumatera Timur. Beberapa peneliti telah mengkaji tokoh ini, di antaranya, Ridhoul Wahidi dan Rafiuddin Afari, ${ }^{13}$ Abdul Qadir Umar Usman alHamidy, et al. ${ }^{14}$ dan Nadzrah Ahmad, et al. ${ }^{15}$ Tetapi, kajian mereka tidak membahas peran Syekh Abdul Halim Hasan dalam tradisi intelektual Islam di Sumatera Timur.

Kajian ini akan mengungkap biografi dan kiprah intelektual Syekh Abdul Halim Hasan di Sumatera Timur. Kajian ini adalah 
hasil penelitian terhadap seorang ulama ${ }^{16}$ yang didekati dengan pendekatan sejarah ${ }^{17}$ dan pendekatan sejarah sosial. ${ }^{18}$ Dalam penelitian ini, akan diteliti beberapa aspek dari figur Syekh Abdul Halim Hasan yang meliputi biografi tokoh, karya monumental dan kiprahnya dalam bidang akademik sampai politik. ${ }^{19}$ Adapun prosedur yang digunakan dalam riset ini mencakup empat langkah, yakni heuristik, kritik sumber, analisis/interpretasi, serta historiografi. ${ }^{20}$

\section{Hasil dan Pembahasan}

\section{Keluarga dan Masa Kecil Syekh Abdul Halim Hasan}

Syekh Abdul Halim Hasan (selanjutnya disebut dengan Abdul Halim) lahir di sebuah kampung yang bernama Limau Sundai terletak di sebelah barat kota Binjai, sebuah kota praja (gemeente) yang dahulu merupakan bagian dari Kesultanan Langkat dan sekarang merupakan sebuah kotamadya pada tanggal 15 Mei $1901 .{ }^{21}$ Orang tuanya bernama Hasan yang bekerja sebagai petani dan berasal dari Manambin, Mandailing Julu dan bermarga Daulay. ${ }^{22}$ Abdul Halim menghabiskan waktu sehari-hari untuk membaca buku pelajaran, di samping membantu orang tuanya. Melihat karya-karyanya, tampak bahwa Abdul Halim sejak kecil termasuk si "kutu buku". Bahkan tidak berlebihan jika disebut ciri keulamaannya telah tampak sejak kecil yang ditunjukkannya dengan ketekunan dalam melaksanakan salat fardu lima waktu. Tidak itu saja, ia juga merupakan anak yang rajin menuntut ilmu, terlebih-lebih ilmu agama. ${ }^{23}$ Sebagaimana pada umumnya tokoh-tokoh berdarah Mandailing, Abdul Halim memiliki semangat kepeloporan, warak, tegar, bijaksana, suka bekerja keras, suka berargumentasi dan konsisten dalam pendiriannya. ${ }^{24}$

Abdul Halim merupakan anak-laki-laki tertua dari 6 bersaudara. Dalam keluarganya anak laki-laki berjumlah 4 orang dan anak perempuan berjumlah 2 orang. Sementara itu, ia memiliki dua 
orang istri. Dari istri pertama (Rahma Lubis), ia memiliki 8 (delapan) orang anak, dan dari istri keduanya (Hj. Sarifah Batubara), ia memiliki 7 (tujuh) orang anak. Amru Daulay yang juga merupakan mantan Bupati Kabupaten Mandailing Natal adalah anak tertua dari istri kedua Syekh Abdul Halim Hasan..$^{25}$

\section{Studi Keagamaannya}

Sewaktu Abdul Halim berusia tujuh tahun, yakni tepatnya pada tahun 1908, ia mengenyam pendidikan di Sekolah Rakyat (SR) di Binjai. Pada masa ini, ia sudah mempelajari ilmu agama Islam dengan bimbingan sejumlah ulama yang terkenal di Sumatera Timur. Di antara ulama tempat ia menimba ilmu yaitu Fakih Saidi Haris, Haji Abdullah Umar, Syekh Muhammad Nur Ismail, Syekh Samah, KH. Abdul Karim dan Syekh Hasan Maksum. ${ }^{26}$ Tidak ditemukan informasi tentang keahlian para gurunya, selain Syekh Hasan Maksum yang ahli dalam bidang fikih, tauhid, dan tasawuf. Akan tetapi, melihat keahlian Abdul Halim dalam bidang fikih, sejarah, hadis terlebih lagi tafsir, bisa dipastikan bahwa ia belajar kepada banyak guru dengan keahlian yang berbeda-beda.

Pada tahun 1926, sewaktu musim haji, Abdul Halim sempat memperdalam ilmu-ilmu keislaman kepada ulama di Arab Saudi yang berada di kota Makkah yang bernama Syekh Mukhtar alTharid. ${ }^{27}$ Ilmu-ilmu yang menjadi keistimewaan Abdul Halim adalah ilmu tafsir, hadis, sejarah dan fikih. ${ }^{28}$ Ia bukan saja belajar ilmu agama, tetapi juga ilmu-ilmu umum. Tercatat bahwa ia belajar ilmu-ilmu umum kepada Jamaluddin Adinegoro tentang pers/jurnalistik dan politik pada tahun 1930 di Medan, serta belajar Bahasa Inggris kepada M. Ridwan yang merupakan pensiunan Kepala Jawatan Penerangan Kabupaten Langkat pada tahun $1930 .^{29}$ Membaca aktivitas Abdul Halim sejak muda, dapat dikatakan untuk ukuran masanya, ia telah memiliki kesadaran global. Dalam 
suasana ini, kemampuan pers dan jurnalistik serta bahasa merupakan sesuatu yang tidak bisa ditawar-tawar lagi agar tidak tergilas dalam perang informasi tersebut.

Sekitar tahun 1920 sampai dengan 1927, masyarakat agama di Binjai dipengaruhi paham tarekat. Pendalaman dalam ilmu fikih, ilmu-ilmu alat dan sejarah sangat terbatas, sedang perdebatan dalam Ilmu Kalam atau Tauhid sangat menonjol. Ia pada mulanya mempelajari ilmu tarekat sesuai anjuran orang tuanya, tetapi kemudian ia lebih tertarik untuk mendalami ilmu fikih, ilmu alat dan sejarah dari KH. Abdul Karim. ${ }^{30}$ Dengan demikian, ketekunannya pada ilmu-ilmu tarekat sudah mulai berkurang. Hal ini sedikit banyaknya kurang disenangi orang tuanya. Situasi demikian pernah ia ceritakan kepada teman akrabnya. Diceritakan bahwa pada suatu malam ia terlambat pulang ke rumah berhubung sampai larut malam terus belajar kepada KH. Abdul Karim. Sampai di rumah, orang tuanya tidak membukakan pintu. Tetapi tidak tahu bagaimana pada pagi harinya, ia sudah berada di dalam rumah, bersiap-siap untuk salat subuh berjamaah dengan orang tuanya di dalam rumah. ${ }^{31}$

Dalam perjalanan selanjutnya, tidak ditemukan data yang akurat tentang pengembaraan ilmiah Abdul Halim. Ada yang mengatakan ia adalah alumni Timur Tengah, sementara ada juga yang mengatakan bahwa ia bukan lulusan Timur Tengah. Di antara yang mengatakan bahwa ia bukan lulusan Timur Tengah adalah Abdullah Syah. Abdullah Syah adalah salah satu murid dari Abdul Halim Hasan. ${ }^{32}$ Secara formal, memang ia bukanlah alumni perguruan tinggi di Timur Tengah. Namun secara nonformal, ia adalah murid dari Syekh Mukhtar al-Tharid seorang ulama terkenal Arab Saudi kelahiran Bogor sebagaimana telah dikemukakan di atas. Ia belajar kepada Syekh Mukhtar al-Tharid sewaktu menunaikan ibadah haji ke Makkah pada tahun 1926. Meskipun hanya satu tahun, ia belajar kepada Syekh Mukhtar al-Tharid, namun karena 
kecerdasan yang dimilikinya, diyakini bahwa ia sangat menguasai keilmuan yang diajarkan oleh Syekh Mukhtar al-Tharid. Hal ini dibuktikan oleh pengakuan L.M. Isa, Basyral Hamidy Harahap, Amru Helmy Daulay, Lahmuddin Nasution, Abdullah Syah, M. Yasir Nasution, Mahmud Aziz Siregar, Sariani As, Azhari Akmal Tarigan dan Agus Khair yang mengatakan bahwa Syekh Abdul Halim Hasan adalah seorang guru yang mahir dalam membaca dan menelaah kitab-kitab khazanah klasik (kitab kuning). ${ }^{33}$

\section{Dari Akademik Sampai Politik}

Karir Syekh Abdul Halim Hasan diawali pada tahun 1920. Ketika itu, ia telah mulai menjadi guru bantu pada Madrasah Jami'atul Khairiyah di Binjai. Selanjutnya, pada tahun 1927 madrasah tersebut merubah nama dengan Madrasah al-Arabiyah (Arabiyah School) atas gagasan Abdul Halim Hasan dimana ia sendiri yang menjadi mudîr-nya. ${ }^{34}$

Akhir tahun 1927 bisa dikatakan sebagai suatu zaman peralihan dari paham yang statis ke paham yang dinamis menuju perubahan, terutama dalam bidang pendidikan agama yang harus diubah sedemikian rupa, agar sekolah-sekolah agama tidak dipandang sebagai sekolah-sekolah liar. Keadaan demikian menyebabkan KH. Abdul Karim, mudîr Madrasah Jami’atul Khairiyah dan masyarakat Kedai Panjang Binjai yang membangun madrasah, memberikan kepercayaan penuh kepada Syekh Abdul Halim Hasan untuk menjadi mudir madrasah selanjutnya. ${ }^{35}$

Ketika Syekh Abdul Halim Hasan menjadi mudîr, ada beberapa gagasan terkait dengan manajemen pendidikan yang dilakukan dengan tujuan untuk menyesuaikan dengan situasi dan kondisi pada waktu itu. Di antara yang digagasnya adalah merubah nama Madrasah Jami’atul Khairiyah dengan Madrasah Arabiyah (Arabiyah School). Kemudian, dengan daya upayanya, 
ia menyusun tenaga pengajar dengan bermacam-macam keahlian, antara lain, pembelajaran Agama secara Holistik diampu oleh Usman Do'a dan Aja 'Arif, pembelajaran Agama dan Ilmiah diampu oleh A. Rahim Haitami, dan Zainal Arifin Abbas; serta pembelajaran Agama dan Pemuda diampu oleh M. Ilyas Amin. ${ }^{36}$

Oleh Syekh Abdul Halim Hasan, pendidikan di madrasah tersebut didasarkan kepada kesanggupan dalam mengeksplor atau pengembangan diri. Artinya, para pelajar diaktifkan/diperbolehkan membentuk organisasi baik di dalam maupun di luar madrasah sesuai dengan peningkatan hidup masyarakat. Ia juga berupaya untuk menyebarluaskan ide, gagasan, dan buah pikirnya dengan tujuan memperluas hubungan ke tengah masyarakat dengan usaha-usaha antara lain seperti mengarang di majalah-majalah, mengarang buku-buku agama, menerjemahkan buku-buku sejarah Islam, dan menyusun tafsir Alquran. ${ }^{37}$

Dari kutipan di atas, ada kesan bahwa Syekh Abdul Halim Hasan telah menerapkan manajemen modern dalam mengelola madrasah. Salah satu cirinya adalah bahwa ia menempatkan seseorang sesuai dengan keahliannya masing-masing. Adalah sebuah kemajuan yang ditunjukkan olehnya dalam pengelolaan madrasah. Artinya, ada penekanan perubahan proses maupun hasil dari tradisional ke modern, atau dari cara-cara lama kepada cara-cara yang baru. ${ }^{38}$ Tidak hanya itu, dari segi nama madrasahnya saja sudah kelihatan bahwa penggunaan bahasa Inggris sebagai ciri modernisasi dalam pendidikan. Kemudian, ia juga memotivasi para siswa untuk membentuk organisasi, baik di dalam maupun di luar madrasah. Tercatat ada beberapa organisasi yang terbentuk di Kota Binjai berawal dari madrasah ini, misalnya al-Hilal (Organisasi Pemuda Kampung Limau Sundai) dan Majelis Syar'i. Usaha ini tidak dilakukan secara mandiri, sebab ia dibantu oleh guru lainnya. Tentu hal ini dilakukan sebagai pengantar masyarakat untuk meningkatkan ilmu pengetahuan serta sadar dengan harga 
diri, di samping memikirkan adanya perubahan-perubahan di tengah-tengah masyarakat Indonesia. ${ }^{39}$

Pada tahun 1937, oleh Syekh Abdul Halim Hasan, Madrasah Arabiyah School itu diganti pula namanya dengan Madrasah Arabiyah Litstsanawiyah hingga kalimat Arabiyah Schooldihilangkan. Perubahan itu dipandang oleh masyarakat sebagai suatu pandangan yang modern dan futuristik, memandang jauh ke depan untuk kemajuan di masa mendatang. ${ }^{40}$ Pada tahun 1942, ia mendapat musibah, sebab rumahnya di kampung Limau Sundai hancur akibat banjir yang menimpa kampung itu. Sebab itu, ia ditampung di lokal Madrasah Arabiyah bersama keluarganya. ${ }^{41}$

Sebagai akibat banjir tersebut, kitab-kitab karya Syekh Abdul Halim Hasan yang sangat banyak menjadi basah dan berlumpur. Ketika kitab-kitab itu dibersihkan murid-muridnya dan dijemur, tiba-tiba datanglah berziarah T. Amir Hamzah yang ketika itu menjadi Pangeran Langkat Hulu di Binjai. ${ }^{42}$ Setelah berjumpa dengan Abdul Halim dan keluarganya, lalu T. Amir Hamzah mendatangi tempat penjemuran kitab-kitabnya di halaman Masjid Raya Binjai. Melihat keadaan buku yang mengalami kerusakan, T. Amir Hamzah berkata kepada Abdul Halim: "mudah-mudahan Tiga Serangkai tetap tabah menghadapi takdir”. Yang dimaksud dengan tiga serangkai ialah kata-kata sanjungan T. Amir Hamzah kepada Abdul Halim Hasan, Abdurrahim Haitami dan Zainal Arifin Abbas, penyusun Tafsir al-Qur'an al-Karim. ${ }^{43}$

Mulai tahun 1920, Syekh Abdul Halim Hasan telah mengajar di Binjai. Di kota ini, ia merupakan guru yang paling lama mengajar, yaitu sampai tahun 1947. Pelajaran yang diberikan olehnya selama masa tersebut dianggap sebagai suatu reformasi dan modernisasi terhadap pendidikan/pelajaran dan pengetahuan agama di kala itu. Terutama karena di dalam pelaksanaannya dilakukan dengan bijaksana, di mana pokok-pokok masalah diuraikan secara terbuka 
dan akuntabel, serta dalam mengambil kesimpulan dilakukan secara adil yang tidak dipengaruhi golongan apapun.

Kemudian setelah tahun 1947, Syekh Abdul Halim Hasan berpindah-pindah mengajar. Barangkali disebabkan oleh perjuangaan di era kemerdekaan ketika itu. Sejak tahun 1947 sampai tahun 1948, ia mengajar di Kutaraja (sekarang Banda Aceh). Dari tahun 1948 sampai tahun 1950, ia berada di Langsa, dan dari tahun 1950 sampai wafatnya tahun 1969, ia mengajar di Binjai dan sekitarnya serta di kota-kota lain yang ada di Sumatera Utara. ${ }^{44}$

Syekh Abdul Halim memiliki sejumlah murid yang berkiprah di Sumatera Utara. Pertama, Zainal Arifin Abbas, sesepuh Partai Persatuan Pembangunan Wilayah Sumatera Utara. Kedua, Amru Daulay yang pernah menjadi Dekan Fakultas Hukum USU Medan. Ketiga, Ahmaddin yang merupakan dosen Fakultas Syariah IAIN Sumatera Utara. Keempat, A. Karim YS. yang pernah menjadi Kepala Bagian Koordinasi dan Pengawasan Perwakilan Departemen Agama Propinsi Sumatera Utara. Kelima, Izuddin Qadi yang pernah menjadi Kepala Penerangan Mobil Jawatan Penerangan Propinsi Sumatera Utara di Medan. Keenam, Zainal Abidin Nurdin yang pernah menjadi anggota Dewan Konstituante..$^{45}$ Ia juga memiliki murid di Malaysia, di antaranya adalah M. Ahmad Syah bin H. Abd. Jabbar (Qadhi Johor) dan M. Bahauddin (ahli nahu di Kelantan). ${ }^{46}$ Dua nama terakhir membuktikan bahwa Syekh Abdul Halim Hasan juga memiliki murid di luar negeri. Hal ini juga membuktikan bahwa ia juga mengajar sampai ke luar negeri.

Selain dalam bidang pendidikan, Syekh Abdul Halim Hasan juga memiliki karir yang cemerlang dalam bidang organisasi baik sosial maupun politik. Pada masa penjajahan Belanda, ia merupakan anggota pemimpin Ikhwan al-Shafa, perhimpunan para ulama/intelektual di Medan sekarang ICMI pada tahun 1927. Ia juga merupakan Ketua Umum al-Hilal (Organisasi Pemuda) 
Kampung Limau Sundai tahun 1927. Selanjutnya, secara berturutturut, ia merupakan mudîr Madrasah Arabiyah School di tahun 1927, anggota Pengurus Pembangunan Perguruan Taman Siswa Binjai pada tahun 1936, penasihat Pengurus Arabiyah School di Binjai tahun 1927, anggota Majelis Syar'iy tahun 1937 di Binjai, serta penasihat Al Jam'iyatul Washliyah tahun 1938 di Binjai. ${ }^{47}$ Pada masa penjajahan Jepang, ia merupakan anggota pengurus BOMPA (Jepang) tahun 1934 di Binjai, anggota Majelis Tarjih Muhammadiyah tahun 1943 di Binjai, serta merupakan Ketua Umum Majelis Islam Tinggi (MIT) tahun 1943 di Binjai. ${ }^{48}$

Pada masa detik-detik Proklamasi Kemerdekaan 17 Agustus 1945, Syekh Abdul Halim Hasan merupakan Ketua Sidang Majelis Islam Tinggi (MIT) pada tanggal 6 September 1945 bertempat di gedung madrasah Arabiyah School Binjai. Setelah adanya dua buah telegram: pertama dari Djamaluddin Adinegoro, yaitu ditujukan kepada Syekh Abdul Halim sebagai Ketua Majelis Islam Tinggi (MIT) Binjai, dan yang kedua dari Buya A.R. Sutan Mansyur (Ketua Muhammadiyah Sumatera) yang ditujukan kepada Abdul Rahim Haitami (Ketua Muhammadiyah Cabang Binjai). Kedua buah telegram itu dikirim dari Bukit Tinggi (Sumatera Barat). Isi kedua telegram adalah menyatakan bahwa Indonesia sudah merdeka, yang diproklamirkan oleh Soekarno-Hatta, atas nama Bangsa Indonesia pada tanggal 17 Agustus 1945. Pemerintah Republik Indonesia, Mr. Teuku Muhammad Hasan sebagai Gubernur Sumatera. Untuk mendukung proklamasi 17 Agustus 1945, di Kota Binjai dan Langkat dikibarkan bendera merah putih dan persiapan pembentukan Pemerintahan Republik Indonesia di kota Binjai dan Langkat. Telegram diterima pada pukul 11.00 WIB di Binjai. Dengan adanya kedua telegram dari Bukit Tinggi tersebut di atas, rapat penetapan dan memutuskan pada hari itu juga bendera merah putih dikibarkan di Kota Binjai pertama kali. Pengibaran bendera merah putih dilaksanakan bertempat 
di Jalan Kebun Lada (sekarang Jalan Perintis Kemerdekaan) di Binjai. $^{49}$

Mr. Teuku Muhammad Hasan, Gubernur Sumatera, menginstruksikan kepada seluruh rakyat Sumatera pada tanggal 4 Oktober 1945, agar rakyat dan masyarakat menyusun/membentuk Pemerintahan Republik Indonesia di daerah masing-masin, dari desa sampai kabupaten, beserta membentuk Komite Nasional Indonesia (KNI) dan Barisan Pemuda Indonesia (BPT) yang telah diresmikan oleh Gubernur pada tanggal 30 September 1945 bertempat di Perguruan Taman Siswa di Jalan Amplas Medan. Bersama dengan para pemuda dan masyarakat, pada tanggal 5 Oktober 1945, ia mengadakan rapat bertempat di gedung Madrasah Arabiyah School pukul 10.00 WIB membentuk/menyusun Pemerintahan Republik Indonesia untuk daerah Kota Binjai dan Langkat. Rapat memutuskan daftar nama-nama para Camat/Asisten Wedana, Wedana, Bupati/Asisten Residen diajukan kepada Gubernur Sumatera untuk mendapat pengesahan dan sistem kerajaan/feodal dihapuskan. ${ }^{50}$

Kemudian pada masa ini, secara berturut-turut, Syekh Abdul Halim Hasan memimpin sejumlah organisasi. Ia menjadi Ketua Umum pasukan "Hizbullah-Sabilillah-Mujahidin," Komando Sektor Barat Utara Front Medan Area di Binjai dari tanggal 7 November 1945 sampai 21 Juli 1947 di Binjai, Ketua Persatuan Perjuangan (volksvront) Langkat Binjai sejak 15 Januari 1946 ssampai 21 Juli 1947 di Binjai, Ketua Makam Syuhada (makam pahlawan) sejak tanggal 15 Januari 1946 sampai 21 Juli 1947 di Binjai, anggota Dewan Pertahanan RI Sumatera Timur di Pematang Siantar sejak tanggal 15 Januari 1946 sampai 26 Agustus 1947 di Langsa, serta Kepala Jawatan Agama Kabupaten Langkat/Binjai sejak tahun 1946 sampai pensiun. ${ }^{51}$

Selanjutnya pada masa Agresi I dan II, Syekh Abdul Halim Hasan merupakan anggota Staf Gubernur Militer Aceh Langkat dan Tanah Karo dengan pangkat Letnan Kolonel Titulir, dengan 
pengangkatan berdasarkan keputusan Wakil Presiden/Wakil Panglima Tertinggi Drs. Mohammad Hatta, Nomor 6/WKP/SUM/46 Tanggal 26 Agustus 1947 dari Bukit Tinggi sampai tahun 1950 di Kutaraja (Banda Aceh). Ia juga merupakan anggota DPRD Provinsi Aceh di Kutaraja (Banda Aceh) dari tahun 1947 sampai tahun 1950, anggota pimpinan perbekalan Res. V.X TNI KSBO di Langsa (Aceh Timur) sejak 1947 sampai tahun 1950. Kemudian, secara berturut-turut, ia menjadi Penasihat Local Yoint Comitte(YLC) dari tahun 1949 sampai tahun 1950 di Langsa (Aceh Timur), anggota pengurus pembangunan Sekolah Menengah Islam Modern (MIM) di Langsa dari tahun 1949 sampai tahun 1950, anggota Panitia Pengurus Penolong Pemerintah Pusat Yogyakarta (P4RD) di Langsa tahun 1949 sampai tahun 1950, Ketua Zending Islam Kabupaten Langkat dan Aceh Timur di Langsa dari tahun 1948 sampai tahun 1950, serta Pimpinan Redaksi penerbitan majalah bulanan Islam "Menara" dari tahun 1948 sampai tahun 1950 di Langsa (Aceh Timur). ${ }^{52}$

Selanjutnya, Syekh Abdul Halim Hasan berkarir sebagai Kepala Jawatan Agama Kabupaten Langkat/Binjai sampai pensiun. Kemudian yang fenomenal adalah bahwa ia menjadi inisiator pelaksanaan dua kegiatan. Pertama, Musabaqah Tilawatil Qur'an (MTQ) yang pertama kali se-Sumatera Timur, yang dilaksanakan pada tahun 1951 di Masjid Raya Binjai. MTQ yang dilaksanakan secara nasional saat ini. Kedua, malam perayaan Lailatul Mina, suatu perayaan yang mendapat sambutan hangat dari masyarakat Islam Kota Binjai dan sekitarnya. Perayaan ini merupakan yang pertama kali dilaksanakan di Indonesia yang diadakan pada tahun 1957. Kemudian, ia merupakan anggota pengurus pembangunan Universitas Islam Sumatera (UISU) di Medan, dosen UISU di Medan, anggota BKS-Ulama Militer Sumatera Utara di Medan, anggota pengurus pembangunan Masjid Agung Medan, Pemrasaran Kongres Ulama Islam se-Indonesia di Medan, serta penasihat 
kesatuan aksi pengganyangan pengkhianatan G.30S/PKI Kabupaten Langkat dan Kotamadya Binjai. ${ }^{53}$

Dapat disimpulkan bahwa Syekh Abdul Halim Hasan merupakan seorang aktivis di berbagai bidang, tidak hanya pendidikan, akan tetapi juga seorang anggota parlemen, organisator, dan penasihat. $\mathrm{Hal}$ ini menandakan bahwa ia merupakan sosok yang selalu membuat kemaslahatan untuk kemajuan umat.

Jika ditelusuri secara lebih mendalam tentang biografi Syekh Abdul Halim Hasan, akan ditemukan fakta bahwa ada sebuah kesadaran yang tampaknya tertanam dalam diri tokoh ini sejak muda bahwa media yang sangat berpengaruh dan efektif untuk menyampaikan gagasan adalah tulisan. Hal ini dapat dipahami bahwa ia adalah seorang yang gemar membaca buku. Hasilnya kemudian adalah bahwa ia aktif menulis di beberapa media sebagaimana telah dibahas pada bagian sebelumnya. Aktivitas menulis tersebut pada gilirannya menghasilkan beberapa karya di bidang hukum, tafsir, adab dan tauhid. Hasil karyanya tersebut menunjukkan bahwa ia ahli dalam bidang hukum, tafsir, adab dan tauhid.

Meskipun Syekh Abdul Halim adalah seorang pakar dalam bidang hukum/Alquran dan dikenal sebagai seorang pejuang dan pelopor pergerakan melawan penjajahan, tetapi tidak bisa dinafikan bahwa ia juga merupakan sosok yang berjasa dalam bidang pendidikan. Pendidikan sangat penting artinya bagi kehidupan dan kemajuan suatu bangsa. Dengan demikian, pendidikan bukan hanya menjadi tanggung jawab pemerintah, namun juga menjadi tanggung jawab masyarakatnya. Dalam hal ini, ia telah menjadikan dirinya sebagai sosok penting dan memiliki peran dalam konstelasi pendidikan di Kota Binjai.

Aktivitas intelektual Syekh Abdul Halim Hasan di Kota Binjai tidak dapat dipisahkan dari Sekolah Tinggi Agama Islam Syekh H. Abdul Halim Hasan Al-Ishlahiyah Binjai. Sekolah tinggi ini adalah salah satu perguruan tinggi agama Islam tertua di 
Kota Binjai. Bahkan jika ditelusuri dari sejarah pembentukannya, cikal bakal sekolah tinggi ini dimulai dari upaya para ulama lokal untuk mensinergikan kedalaman ilmu pengetahuan keagamaan dengan ilmu-ilmu modern. ${ }^{54}$

Sekolah Tinggi Agama Islam Syekh H. Abdul Halim Hasan al-Ishlahiyah Binjai ini berawal dari Jam'iyatul Khairiyah yang didirikan pada tanggal 22 Nopember 1922 di kompleks Masjid Raya Binjai ${ }^{55}$ Lokasi ini merupakan wakaf dari Sultan Langkat yang diperuntukkan bagi pembinaan moralitas dan intelektualitas umat pada saat itu. Pada gilirannya, Jam'iyatul Khairiyah menjadi pusat pengajian modern bagi umat Islam yang bertempat tinggal di wilayah Binjai dan Langkat. Pada saat berdirinya Jam'iyatul Khairiyah, Syekh Abdul Halim hanya sebagai tenaga pendidik saja. Ia hanya bertugas untuk mengajar di madrasah yang dinakhodai oleh KH. Abdul Karim. ${ }^{56}$

Pada perkembangan selanjutnya, tepatnya pada tahun 1927, setelah KH. Abdul Karim diangkat menjadi Mufti Kesultanan Langkat menggantikan H. M. Nur al-Faqih yang wafat pada tahun tersebut, barulah madrasah dipercayakan kepada Syekh Abdul Halim. Ketika madrasah ini dipimpin olehnya, secara simultan aktivitasnya dalam bidang pendidikan semakin intens. Artinya, cara berpikirnya semakin berkembang dan futuristik dalam mengembangkan lembaga pendidikan. Hal ini terbukti dengan gagasannya yang merubah nama dari Jam'iyatul Khairiyah dengan Madrasah al-Arabiyah (Arabiyah School). ${ }^{57}$ Nama ini dipandang sebagai sebuah langkah modernisasi pada lembaga pendidikan. Hal ini sesuai dengan alasan mengapa nama madrasah tersebut diganti, yaitu untuk menyesuaikan dengan situasi dan kondisi pada waktu itu, yakni kondisi yang semakin maju dan berkembang, dan penggunaan bahasa Inggris pada nama madrasah tersebut juga disebut-sebut sebagai ciri modernisasi dalam pendidikan. ${ }^{58}$ Perubahan nama ini juga membawa angin perubahan dan atmosfir 
baru bagi dunia pendidikan Islam di Binjai-Langkat pada saat itu. Bagaimana tidak, nama Arabiyah School pada mulanya terdengar sedikit janggal di kalangan aktivis pergerakan pendidikan Islam pada saat itu, karena menggabungkan terminologi Arab dan Inggris secara bersamaan. Jika diamati dengan seksama, melalui nama Arabiyah School ini saja, orang sudah menangkap bahwa inisiator lembaga pendidikan tersebut, berkeinginan untuk mengombinasikan antara kedalaman pendidikan agama dengan keluasan ilmu-ilmu modern.

\section{Karya Akademik}

Syekh Abdul Halim Hasan selain sebagai seorang ulama di zamannya, juga merupakan seorang penulis produktif. Namun sayang, tidak banyak tulisan yang berhasil dikumpulkan. Pertama, Tafsir al-Qur'an al-Karim. Kitab ini mengkaji tentang tafsir Alquran. Kitab yang ditulis secara kolektif bersama dengan Zainal Arifin Abbas dan Abdul Rahim Haitami ini masih ditulis sebanyak 8 (delapan) jilid dan masih membahas 8 (delapan) juz Alquran dan belum selesai. Hal ini karena sebelum menyelesaikan tulisan ini, Syekh Abdul Halim meninggal dunia. ${ }^{59}$ Manuskrip yang utuh dari kitab ini hanya ada 6 (enam) jilid, di mana dari 6 jilid tersebut membahas tentang tafsir Alquran yang dimulai dari surah al-Baqarah ayat 1 sampai dengan surah al-Mầidah ayat 82 . Secara terperinci, pada jilid 1 membahas surah al-Baqarah ayat 1-141. Jilid 2 membahas surah al-Baqarah ayat 142-252. Jilid 3 membahas surah al-Baqarah ayat 253-286 dan surah Âli 'Imrân ayat 1-91. Jilid 4 membahas surah Âli 'Imrân 92-200 dan surah al-Nisâ' ayat 1-23. Jilid 5 membahas surah al-Nisâ' ayat 25-147. Jilid 6 membahas surah al-Nisâ' ayat 148-176 dan surah al-Mâidah ayat 1-82. Kitab ini diterbitkan oleh Penerbit al-Ichwan pada tahun 1383/1963. Penerbit al-Ichwan merupakan terbitan bukubuku agama yang berada di Kota Medan. Keunggulan kitab ini 
terletak pada kemampuan penulisnya dalam menafsirkan setiap ayat yang ditafsirkan. Hal ini terungkap dari testimoni yang disampaikan oleh beberapa ulama baik lokal maupun nasional, bahwa kemampuan penafsiran ulama tiga serangkai sangat baik pada zamannya.

Kedua, Sejarah Fiqh Islam. Buku ini membahas tentang kewajiban seorang Muslim serta seluruh permasalahan yang terkait dengan hukum peribadatan dan kemasyarakatan. Masalah-masalah agama tentang uraian hukumnya dikupas berdasarkan ayat-ayat Alquran dan hadis-hadis sahih. ${ }^{60}$ Buku ini juga menguak dimensi kesejarahan dalam konteks fikih Islam, di samping juga membahas sebagaimana dijelaskan di atas. Fisik buku ini tidak ditemukan secara utuh, namun yang pasti buku ini membahas tentang 161 masalah keagamaan. Buku ini diterbitkan oleh Penerbit al-Ichwan, namun tidak diketahui secara pasti tahun terbitnya. Penerbit al-Ichwan merupakan terbitan buku-buku agama kota Medan. Keunggulan buku ini terletak pada kajian yang secara komprehensif membahas dan mengkaji permasalahan keislaman dan keagamaan dalam kemasyarakatan dengan jelas disertai dengan uraian-uraian yang diperkuat dengan Alquran dan Hadis.

Ketiga, Wanita dan Islam. Buku ini membahas tentang wanita dan hak-haknya berdasarkan Alquran dan hadis. Pembahasannya meliputi 38 (tiga puluh delapan) bab yang berkaitan tentang wanita. ${ }^{61}$ Secara sederhana, ke-38 bab tersebut berisi tentang alasan-alasan Alquran dan Hadis tentang wanita dan hak-haknya, wanita itu belahan laki-laki, ganjaran wanita di akhirat, lakilaki dan wanita secara bersama-sama melakukan syiar agama, wanita berhak memberikan keamanan, wanita melakukan tugas amar makruf dan nahi mungkar, wanita bersama-sama laki-laki membai'ah Rasulullah, hak wanita dalam ilmu pengetahuan, hak-hak wanita yang berhubungan dengan harta, haknya berhubungan dengan puasa, mahar istri, hak-hak wanita dalam perkawinan, 
wali nikah dan kemerdekaan wanita dalam pernikahan, rukun perkawinan dalam Islam, persamaan hak antara laki-laki dan wanita, tugas suami istri dalam fitrah kejadian masing-masing, mengepalai rumah tangga dengan jalan musyawarah, bukan dengan istibdad, tugas laki-laki dan wanita dan amal-amal keduanya, kelebihan laki-laki dari wanita (hak riyasah) istri yang saleh dan nusyûz, sejarah poligami, perbaikan poligami sesudah Islam, istri-istri Nabi (hikmah perkawinannya dengan poligami sesudah hijrah), hikmah-hikmah umum dalam perkawinan Nabi, sebabsebab khusus dari perkawinan Nabi Muhammad SAW. sesudah Khadijah, siap-siapa istri Rasulullah dan bagaimana caranya Nabi menghadapi setiap istrinya, kehidupan Nabi dalam rumah tangganya, alat hijab dan sebab turunnya, buah tuntunan Alquran dan sunnah pada istri-istri Nabi, thalak, fasakh, khulu', ila, dan zhihar, sebab-sebab yang membawa perceraian suami istri, menghalangi thalak dalam Islam dan memelihara hak wanita, hak wanita dalam fasakh dan khulu', berkabung karena wafat suami, adab wanita muslimah, perintah kudung pada wanita, dan masalah kudung. Buku ini diterbitkan oleh Penerbit alIchwan, namun tidak diketahui secara pasti tahun terbitnya. Penerbit al-Ichwan merupakan terbitan buku-buku agama kota Medan. Keunggulan buku ini terletak pada kajian yang secara komprehensif membahas dan mengkaji permasalahan wanita.

Keempat, Hikmah Puasa. Buku ini membahas tentang hikmah puasa dengan berbagai persoalannya. Buku ini diuraikan dengan landasan Alquran dan hadis. ${ }^{62}$ Buku ini diterbitkan oleh Penerbit al-Ichwan, namun tidak diketahui secara pasti tahun terbitnya. Keunggulan buku ini terletak pada kajian yang secara komprehensif membahas dan mengkaji permasalahan puasa yang dikaitkan dengan landasan al-Qur'an dan hadis.

Kelima, Adab Kesopanan Islam. Buku ini membahas tentang adab dan pergaulan yang membawa cinta kepada Allah. Dalam 
kata pengantar di buku ini, ia menuturkan bahwa hanya dengan mengikuti ajaran Rasulullah serta para sahabat dan orang-orang saleh terdahulu, adab dan pergaulan bisa menjadi ibadah yang membawa cinta kepada Allah. Buku ini banyak mengutip pendapat Imam al-Ghazâlî dalam kitab Ihyyâ' 'Ulûm al-Dîn. ${ }^{63}$ Buku ini diterbitkan oleh Penerbit al-Ichwan pada tahun 1382/1962. Keunggulan buku ini terletak pada kajian yang secara komprehensif membahas dan mengkaji permasalahan adab dan kesopanan dalam Islam disertai dengan uraian-uraian yang diperkuat dengan Alquran dan Hadis.

Keenam, Tafsir al-Ahkam. Kitab ini merupakan salah satu karya Syekh Abdul Halim. Tidak diketahui kapan dimulai penulisannya, karena memang tidak ada disebutkan dan dijumpai, baik dalam tulisannya atau diungkapkan secara lisan. Pada mulanya, tafsir ini hanya berbentuk naskah dan tidak pernah diterbitkan semasa hidupnya. Baru kemudian diterbitkan setelah setelah ada gagasan dari Azhari Akmal Tarigan, yang bekerja sama dengan Agus Khair. Gagasan untuk menerbitkan tafsir ini pun disambut baik oleh putra Syekh Abdul Halim Hasan, yaitu Amru Daulay yang pada saat itu masih menjabat sebagai Bupati Kabupaten Madina sampai pada akhirnya pada tahun 2006, kitab ini dapat diterbitkan. Tafsir al-Ahkam adalah tafsir tematik yang hanya membahas tentang ayat-ayat hukum. Dalam hal ini, pengarang hanya menafsirkan 250 ayat hukum. Corak tafsir ini adalah corak fikih dan hukum Islam, sesuai dengan namanya Tafsir al-Ahkam. ${ }^{64}$ Buku ini diterbitkan oleh penerbit Kencana Prenada Media pada tahun 2006. Keunggulan buku ini adalah ulasan yang komprehensif terkait dengan ayatayat hukum dengan tafsiran yang mumpuni.

Ketujuh, Sinar Memantjar dari Mesjid. Buku ini berisi tentang kumpulan artikel tentang musyawarah kemakmuran masjid yang ditulis oleh ulama terkenal yaitu Buya Hamka, Abdul Halim Hasan dan M. Bustami Ibrahim. ${ }^{65}$ Secara umum, artikel-artikel ini mengkaji tentang masjid yang ditujukan kepada pengurus 
Badan Kemakmuran Masjid di Sumatera Timur sebagai panduan dalam manajemen masjid. Buku ini diterbitkan oleh Penerbit alIchwan, namun tidak diketahui secara pasti tahun terbitnya.

Selain karya di atas, sebenarnya ada 8 (delapan) judul buku yang sampai sekarang tidak ditemukan manuskripnya, sehingga buku-buku ini tidak bisa dideskripsikan. Buku-buku tersebut yaitu Lailatul Qadar, Cara Memandikan Mayat, Tarekh Tamaddun Islam, Sejarah Literatur Islam, Tarikh Abi Hasan al-Asy'ari, Poligami dalam Islam, dan Bingkisan Adab dan Hikmah. ${ }^{66}$

\section{Penutup}

Dari uraian di atas dapat ditarik tiga kesimpulan. Pertama, Syekh Abdul Halim Hasan merupakan ulama dari etnis Mandailing yang berhasil menumbuhkan tradisi intelektual Islam di Sumatera Timur. Ia berhasil membangun budaya akademik melalui pendirian madrasah yang telah memberikan pencerahan di Kota Binjai, memiliki sejumlah murid yang berdedikasi dalam kehidupan keagamaan dan kebangsaan, dan menjadi pribadi yang menolak Kolonialisme yang dibuktikannya dengan memperjuangkan dan mempertahankan kemerdekaan Indonesia. Sebab itulah, ia layak digelari sebagai pahlawan nasional. Kedua, Syekh Abdul Halim Hasan merupakan ulama yang tidak saja berdedikasi dalam bidang akademik, tetapi mumpuni dalam bidang keorganisasian. Ia aktif dalam organisasi sosial bahkan terjun dalam bidang politik. Memang, tidak semua ulama mampu memainkan peran ganda seperti ini, dan ia ternyata mampu melakukannya secara meyakinkan. Sebab itulah, ia berperan sebagai pendidik, organisatoris, sampai politisi dengan menjadi seorang anggota parlemen. Ketiga, Syekh Abdul Halim Hasan memiliki sejumlah karya dalam bidang keislaman, khususnya dalam disiplin tafsir, pendidikan, dan fikih. Karya-karya yang belum banyak dikaji, kecuali karyanya 
dalam bidang tafsir. Sebab itu, dipandang penting mengkaji keseluruhan karyanya untuk menemukan peta pemikirannya secara mendalam.

\section{Pustaka Acuan}

Ahmad, Nadzrah, et al. 'Isu-Isu Fiqh dalam Tafsir Al-Qur'an AlKarim Karangan Al-Ustaz H. A. Halim Hasan, H. Zainal Arifin Abbas dan Abdul Rahim Haitami," dalam Jurnal Islam dan Masyarakat Kontemporari, Bil. 17, 2018.

Ahmad, Nadzrah. "Isu-isu Dakwah dalam Al-Qur'an al-Karim," dalam al-Hikmah, Vol. 9, No. 2, 2017.

Al-Hamidy, Abdul Qadir Umar Usman, et al. "Abdul Halim Hasan and His Contributions in Quranic Exegesis in the Malay World," dalam International Journal of Academic Research in Business and Social Sciences, Vol. 7, No. 8, 2017.

Asari, Hasan. Menguak Sejarah Mencari 'Ibrah: Risalah Sejarah Sosial-Intelektual Muslim Klasik. Bandung: Citapustaka Media Perintis, 2006.

Asari, Hasan. Menyingkap Zaman Keemasan Islam. Bandung: Citapustaka Media, 2007.

Azra, Azyumardi. Jaringan Ulama Timur Tengah dan Kepulauan Nusantara Abad XVII dan XVIII: Akar Pembaruan Islam Indonesia, cet. 2. Jakarta: Prenada, 2005.

Dahlan, Zaini. "Islamic Education During Langkat Sultanate Era In 1912-1946: A Historical Study of Jam'iyah Mahmudiyah li Thalibil Khairiyah Langkat," dalam MIQOT:Jurnal IlmuIlmu Keislaman, Vol. XLI, No. 1, Januari-Juni 2017.

Dahlan, Zaini. 'Sejarah Sosial Jam'iyah Mahmudiyah li Thalibil Khairiyah Tanjung Pura Langkat 1892-2016.’Disertasi: Pascasarjana UIN Sumatera Utara, 2017.

Daulay, Haidar Putra. Dinamika Pendidikan Islam di Asia Tenggara. Jakarta: Rineka Cipta, 2009. 
Daulay, Haidar Putra. Historisitas dan Eksistensi Pesantren Sekolah dan Madrasah. Yogyakarta: Tiara Wacana Yogya, 2001.

Daulay, Haidar Putra. Kapita Selekta Pendidikan Islam di Indonesia. Medan: Perdana Mulya Sarana, 2012.

Daulay, Haidar Putra. Sejarah Pertumbuhan dan Pembaruan Pendidikan Islam di Indonesia. Jakarta: Kencana, 2012.

Dewan Harian Cabang Angkatan 45. Catatan Pelaku Sejarah Pengibar Bendera Merah Putih Pertama di Binjai. Binjai: t.p., 1996.

Hamka, et al. Sinar Memantjar dari Mesjid. Medan: Al Ichwan, t.t. Harahap, Basyral Hamidy. "Syekh Abdul Halim Hasan dan Perubahan Sosial," dalam Abdul Halim Hasan. Tafsir AlAhkam. Jakarta: Prenada, 2006.

Harahap, Syahrin. Metodologi Studi Tokoh Pemikiran Islam. Jakarta: Prenada, 2011.

Hasan, Abdul Halim. Adab Kesopanan Islam. Medan: Al Ichwan, 1962.

Hasan, Abdul Halim, et al. Tafsir Al-Qur'anul Karim, Jilid I-VI, cet. 2. Medan: Firma Islamiyah, 1963.

Hasan, Abdul Halim.Tafsir Al-Ahkam. Jakarta: Prenada, 2006.

Hasan, Muhammad. "Inovasi dan Modernisasi Pendidikan Pondok Pesantren," dalam Karsa: Jurnal of Social and Islamic Culture. Vol. 23, No. 2, Desember 2015.

Husin, Djohar Arifin. Tengku Amir Hamzah: Tokoh Pergerakan Nasional, Konseptor Sumpah Pemuda, Pangeran Pembela Rakyat, Tak Pernah Berhenti Mengabdi Untuk Bangsa Sampai Akhir Hayat. Jakarta: Bumi Timur Jaya, 2011.

IAIN Sumatera Utara. Sejarah Ulama-ulama Terkemuka di Sumatera Utara. Medan: MUI Sumatera Utara, 1983.

Ja'far. "Tarekat dan Gerakan Sosial Keagamaan Shaykh Hasan Maksum," dalam Teosofi: Jurnal Tasawuf dan Pemikiran Islam, Vol. 5, No. 2, 2015.

Kuntowijoyo. Pengantar Ilmu Sejarah. Yogyakarta: Tiara Wacana, 2013. 
Mudzhar, M. Atho'. Pendekatan Studi Islam dalam Teori dan Praktek. Yogyakarta: Pustaka Pelajar, 1998.

Muhaimin, et al. Studi Islam dalam Ragam Dimensi dan Pendekatan, cet. 3. Jakarta: Prenada, 2012.

Mukti, Abd. "Madrasah dan Pesantren; Sejarah Pertumbuhan dan Perkembangannya," dalam Asnil Aidah Ritonga dan Marliyah (ed.). Terbuai dalam Studi Sejarah dan Pembaruan Pendidikan Islam. Bandung: Citapustaka Media, 2010.

Mukti, Abd. Konstruksi Pendidikan Islam: Belajar Dari Kejayaan Madrasah Nizamiyah Dinasti Saljuq. Bandung: Citapustaka Media, 2007.

Nasution, M. Amin, dan M. Saleh. Menelusuri Akar Sejarah $M T Q$ Pertama di Indonesia. Binjai: DP MUI Kota BinjaiLPTQ Kota Binjai-STAI Syekh Abdul Halim Hasan al-Ishlahiyah Binjai, 2014.

Nawir Yuslem (ed.). Metodologi dan Pendekatan dalam Pengkajian Islam. Bandung: Citapustaka Media Perintis, 2013.

Nazir, Moh. Metode Penelitian, cet. 3. Jakarta: Ghalia Indonesia, 1988.

Nilan, Pam. "The 'Spirit of Education' in Indonesian Pesantren," dalam British Journal of Sociology of Education, Vol. 30, Issue 2, 2009.

Park, Jaddon, dan Sarfaroz Niyozov. "Madrasa Education in South Asia and Southeast Asia: Current Issues and Debates," dalam Asia Pacific Journal of Education, Vol. 28, Issue 4, 2008.

Siddin, Abdul Jalil, et al. Sejarah al-Ishlahiyah. Binjai: t.p., 1999.

Srimulyani, Eka . "Muslim Women and Education in Indonesia: The Pondok Pesantren Experience," dalam Asia Pacific Journal of Education, Vol. 27, Issue 1, 2007.

Sumardi, Mulyanto. Sejarah Singkat Pendidikan Islam di Indonesia 1945-1975. Jakarta: Dharma Bhakti, 1978.

Syah, Abdullah. "Sambutan," dalam Abdul Halim Hasan. Tafsir Al-Ahkam. Jakarta: Prenada, 2006. 
Syamsuddin, Helius. Metodologi Sejarah. Jakarta: Jalan Pintu Satu, 1996.

Teeuw, A. Indonesia dalam Kegelisahan dan Keberaksaraan. Jakarta: Pustaka Jaya, 1994.

Wahidi, Ridhoul dan Rafiuddin Afari. "Tafsir Al-Ahkam Karya Abdul Halim Hasan Binjani," dalam Jurnal Syahadah, Vol. 3, No. 2, 2015. 


\section{Catatan Akhir:}

${ }^{1}$ Lebih jelas terkait dengan teori masuknya Islam ke Indonesia seperti teori India, teori Arab, teori Benggal, teori Persia, dan teori China bisa dilihat dalam Haidar Putra Daulay, Historisitas dan Eksistensi Pesantren Sekolah dan Madrasah (Yogyakarta: Tiara Wacana Yogya, 2001), h. ix; Haidar Putra Daulay, Sejarah Pertumbuhan dan Pembaruan Pendidikan Islam di Indonesia (Jakarta: Kencana, 2012), h. 11-13; Azyumardi Azra, Jaringan Ulama Timur Tengah dan Kepulauan Nusantara Abad XVII dan XVIII: Akar Pembaruan Islam Indonesia, cet. 2 (Jakarta: Prenada, 2005), h. 2-18.

${ }^{2}$ Haidar Putra Daulay, Kapita Selekta Pendidikan Islam di Indonesia (Medan: Perdana Mulya Sarana, 2012), h. 17.

${ }^{3}$ Deskripsi tentang masjid pada masa klasik bisa dilihat dalam Hasan Asari, Menyingkap Zaman Keemasan Islam (Bandung: Citapustaka Media, 2007), h. 44-45.

${ }^{4}$ Haidar Putra Daulay, Dinamika Pendidikan Islam di Asia Tenggara (Jakarta: Rineka Cipta, 2009), h. 23.

${ }^{5}$ Lihat Abd. Mukti, Konstruksi Pendidikan Islam: Belajar Dari Kejayaan Madrasah Nizamiyah Dinasti Saljuq (Bandung: Citapustaka Media, 2007).

${ }^{6}$ Lihat Abd. Mukti, "Madrasah dan Pesantren: Sejarah Pertumbuhan dan Perkembangannya," dalam Asnil Aidah Ritonga dan Marliyah (ed.), Terbuai dalam Studi Sejarah dan Pembaruan Pendidikan Islam (Bandung: Citapustaka Media, 2010), h. 24-25. Tentang kajian pesantren lebih lanjut, lihat Eka Srimulyani, "Muslim Women and Education in Indonesia: The Pondok Pesantren Experience," dalam Asia Pacific Journal of Education, Vol. 27, Issue 1, 2007, pp. 85-99; Pam Nilan, "The 'Spirit of Education' in Indonesian Pesantren," dalam British Journal of Sociology of Education, Vol. 30, Issue 2, 2009, pp. 219-232.

${ }^{7}$ Azra, Jaringan Ulama, h. 23; A. Teeuw, Indonesia dalam Kegelisahan dan Keberaksaraan (Jakarta: Pustaka Jaya, 1994), h. 45-46.

${ }^{8}$ Azra, Jaringan Ulama, h. 24.

'Tentang madrasah dan perkembangannya, lihat Jaddon Park \& Sarfaroz Niyozov, "Madrasa Education in South Asia and Southeast Asia: Current Issues and Debates," dalam Asia Pacific Journal of Education, Vol. 28, Issue 4, 2008, pp. 323-351.

${ }^{10}$ Mulyanto Sumardi, Sejarah Singkat Pendidikan Islam di Indonesia 19451975 (Jakarta: Dharma Bhakti, 1978), h. 49.

${ }^{11}$ Ibid.

${ }^{12}$ Ibid., h. 49.

${ }^{13}$ Ridhoul Wahidi dan Rafiuddin Afari, "Tafsir Al-Ahkam Karya Abdul Halim Hasan Binjani," dalam Jurnal Syahadah, Vol. 3, No. 2, 2015, pp. 47-64.

${ }^{14} \mathrm{Abdul}$ Qadir Umar Usman Al-Hamidy, et al., "Abdul Halim Hasan and His Contributions in Quranic Exegesis in the Malay World," dalam International Journal of Academic Research in Business and Social Sciences, Vol. 7, No. 8, 2017, pp. 469-477.

${ }^{15} \mathrm{Nadzrah}$ Ahmad, et al., "Isu-Isu Fiqh dalam Tafsir Al-Qur'an Al-Karim Karangan Al-Ustaz H. A. Halim Hasan, H. Zainal Arifin Abbas dan Abdul Rahim Haitami," 
dalam Jurnal Islam dan Masyarakat Kontemporari, Bil. 17, 2018, h. 1-18; Nadzrah Ahmad, et al., "Isu-isu Dakwah dalam Al-Qur'an al-Karim," dalam al-Hikmah, Vol. 9, No. 2, 2017, pp. 78-86.

${ }^{16}$ Lihat Syahrin Harahap, Metodologi Studi Tokoh Pemikiran Islam (Jakarta: Prenada, 2011), h. 7.

${ }^{17}$ M. Atho' Mudzhar, Pendekatan Studi Islam dalam Teori dan Praktek(Yogyakarta, Pustaka Pelajar, 1998), h. 67; Moh. Nazir, Metode Penelitian, cet. 3 (Jakarta: Ghalia Indonesia, 1988), h. 55.63; Muhaimin, et al., Studi Islam dalam Ragam Dimensi dan Pendekatan, cet. 3 (Jakarta: Kencana Prenada Media, 2012), h. 211-214; Nawir Yuslem (ed.), Metodologi dan Pendekatan dalam Pengkajian Islam (Bandung: Citapustaka Media Perintis, 2013), h. 140-158; Helius Syamsuddin, Metodologi Sejarah (Jakarta: Jalan Pintu Satu, 1996), h. 61.

${ }^{18}$ Hasan Asari, Menguak Sejarah Mencari 'Ibrah: Risalah Sejarah Sosial-Intelektual Muslim Klasik (Bandung: Citapustaka Media Perintis, 2006), h. 27.

${ }^{19}$ Harahap, Metodologi Studi, h. 8.

${ }^{20}$ Kuntowijoyo, Pengantar Ilmu Sejarah (Yogyakarta: Tiara Wacana, 2013), h. 69-80.

${ }^{21}$ Lihat Dewan Harian Cabang Angkatan 45, Catatan Pelaku Sejarah Pengibar Bendera Merah Putih Pertama di Binjai (Binjai: t.p., 1996), h. 1. Kesultanan Langkat adalah sebuah pemerintahan di bawah kendali seorang Sultan yang ketika Syekh Abdul Halim Hasan lahir, Kesultanan Langkat dipimpin oleh Sultan Abdul Aziz Abdul Jalil Rahmadsyah. Belakangan Syekh Abdul Halim Hasan memiliki kedekatan dengan ulama-ulama yang berasal dari Tanjung Pura Langkat. Tentunya Kesultanan Langkat menjadi patron Syekh Abdul Halim Hasan dalam memantapkan kedudukannya sebagai seorang mudir di Madrasah Arabiyah School di Binjai. Lihat Zaini Dahlan, "Islamic Education During Langkat Sultanate Era in 1912-1946: A Historical Study of Jam'iyah Mahmudiyah li Thalibil Khairiyah Langkat," dalam MIQOT:Jurnal IImu-IImu Keislaman, Vol. XLI, No. 1 Januari-Juni 2017, h. 144-163.

${ }^{22}$ Basyral Hamidy Harahap, "Syekh Abdul Halim Hasan dan Perubahan Sosial," Abdul Halim Hasan, Tafsir al-Ahkam (Jakarta: Prenada, 2006), h. li.

${ }^{23}$ Lihat dalam IAIN Sumatera Utara, Sejarah Ulama-ulama Terkemuka di Sumatera Utara (Medan: MUI Sumatera Utara, 1983), h. 233.

${ }^{24}$ Hasan, Tafsir Al-Ahkam, h. liii.

${ }^{25}$ Amru Daulay lahir di Binjai tanggal 18 Oktober 1939. Ia pernah menjadi Bupati Kabupaten Mandailing Natal selama dua periode (2000-2010) dan pernah menjadi Dekan Fakultas Hukum USU. Ia merupakan anak tertua dari Syekh Abdul Halim Hasan yang dikenal sebagai seorang ulama tafsir di zamannya. Saat ini ia berdomisili di Medan. Wawancara Achyar Daulay (anak kandung Syekh Abdul Halim Hasan), di Binjai, 15 Agustus 2017.

${ }^{26}$ Terkait dengan guru-guru Syekh Abdul Halim Hasan ini tidak terdapat perbedaan antara satu sumber dengan sumber lainnya. Semua sumber sepakat mengatakan bahwa guru-guru Syekh Abdul Halim Hasan adalah sebagaimana dituliskan di atas. Lihat Dewan Harian Cabang Angkatan 45, Catatan Pelaku Sejarah, h. 1; Abdul Jalil Siddin, et.al., Sejarah al-Ishlahiyah (Binjai: t.t., 1999), h. 1; Hasan, Tafsir Al-Ahkam, h. lix; 
IAIN Sumatera Utara, Sejarah Ulama-ulama, h. 233. Tentang Syekh Hasan Maksum, lihat Ja'far. "Tarekat dan Gerakan Sosial Keagamaan Shaykh Hasan Maksum,” dalam Teosofi: Jurnal Tasawuf dan Pemikiran Islam, Vol. 5, No. 2, 2015.

${ }^{27}$ Syekh Mukhtar al-Tharid merupakan ulama kelahiran Bogor, Jawa Barat pada 14 Februari 1862. Ia adalah ulama ahli syariat dan hakikat. Lihat Dewan Harian Cabang Angkatan 45, Catatan Pelaku Sejarah, h. 1.

${ }^{28}$ Ibid., h. 2.

${ }^{29}$ Siddin, Sejarah al-Ishlahiyah, h. 2. Sayang sekali sampai saat ini tidak diketahui banyak hal tentang tokoh ini. Para penulis biografinya hanya mengatakan bahwa ia adalah guru Syekh Abdul Halim Hasan dalam bidang kajian bahasa Inggris. Karenanya, dapat dikatakan bahwa ia dikenal hanya karena Syekh Abdul Halim Hasan pernah menjadi muridnya.

${ }^{30} \mathrm{Ibid}$.

${ }^{31}$ Ibid.

${ }^{32}$ Abdullah Syah, "Sambutan," dalam Abdul Halim Hasan, Tafsir al-Ahkam (Jakarta: Prenada, 2006), h. xix.

${ }^{33}$ Lebih detail lihat dalam Abdul Halim Hasan, Tafsir Al-Ahkam (Jakarta: Prenada, 2006).

${ }^{34}$ Siddin, Sejarah al-Ishlahiyah, h. 2.

${ }^{35}$ Ibid.

${ }^{36}$ Dewan Harian Cabang Angkatan 45, Catatan Pelaku Sejarah, h. 2.

${ }^{37}$ Ibid., h. 2.

${ }^{38}$ Muhammad Hasan, "Inovasi dan Modernisasi Pendidikan Pondok Pesantren," dalam Karsa: Jurnal of Social and Islamic Culture, Vol. 23, No. 2, Desember 2015, h. 304.

${ }^{39}$ Siddin, Sejarah Al-Ishlahiyah, h. 3.

${ }^{40}$ Ibid., h. 4.

${ }^{41}$ Ibid.

${ }^{42}$ Tengku Amir Hamzah merupakan Pahlawan Nasional 1978 yang lahir di Tanjung Pura, Langkat, Sumatera Utara, pada 28 tanggal Februari 1911 dan meninggal dunia pada 20 Maret 1946 di Kuala Begumit, Binjai. Lihat Zaini Dahlan, Sejarah Sosial Jam’iyah, h. 312-317; Djohar Arifin Husin, Tengku Amir Hamzah: Tokoh Pergerakan Nasional, Konseptor Sumpah Pemuda, Pangeran Pembela Rakyat, Tak Pernah Berhenti Mengabdi Untuk Bangsa Sampai Akhir Hayat (Jakarta: Bumi Timur Jaya, 2011), h. 1.

${ }^{43}$ Siddin, Sejarah al-Ishlahiyah, h. 4.

${ }^{44}$ Ibid., h. 4-5.

${ }^{45}$ Penulis tidak memiliki data yang lengkap terkait biografi sebagian murid-murid Syekh Abdul Halim Hasan di atas. Namun begitu, barangkali secara sederhana dapat dilihat dalam Siddin, Sejarah al-Ishlahiyah, h. 5.

${ }^{46}$ Ibid.

${ }^{47}$ Ibid., h. 7. 
VOL. 2 NO. 1 JANUARI-JUNI 2018

${ }^{48}$ Ibid., h. 7.

${ }^{49}$ Ibid., h. 7.

${ }^{50}$ Ibid., h. 8.

${ }^{51}$ Ibid., h. 8-9.

${ }^{52}$ Ibid., h. 9.

${ }^{53}$ Ibid., h. 10-11.

${ }^{54}$ M. Amin Nasution dan M. Saleh, Menelusuri Akar Sejarah MTQ Pertama di Indonesia (Binjai: Kerjasama antara DP MUI Kota Binjai, LPTQ Kota Binjai, dan STAI Syekh Abdul Halim Hasan al-Ishlahiyah Binjai, 2014), h. 20.

${ }^{55}$ Siddin, Sejarah Al-Ishlahiyah, h. 3.

${ }^{56}$ Ibid., h. 4. Pada periode ini tidak banyak aktivitas yang dilakukan oleh Syekh Abdul Halim Hasan dalam bidang pendidikan di Kota Binjai.

${ }^{57}$ Ibid., h. 2.

${ }^{58}$ Ibid., h. 5.

${ }^{59}$ Penulis hanya memiliki 6 (enam) jilid kitab Tafsir Al-Qur'anul Karim karya ulama tiga serangkai ini. Lihat dalam Abdul Halim Hasan, et al., Tafsir Al-Qur'anul Karim, Jilid I-VI, cet. 2 (Medan: Firma Islamiyah, 1963).

${ }^{60}$ Lihat Abdul Halim Hasan, Adab Kesopanan Islam (Medan: Al Ichwan, 1382/ 1962), h. 128.

${ }^{61}$ Lihat Hamka, et al., Sinar Memantjar dari Mesjid (Medan: Al Ichwan, t.t.).

${ }^{62}$ Hasan, Adab Kesopanan, h. 129.

${ }^{63}$ Lihat dalam Abdul Halim Hasan, Adab Kesopanan Islam (Medan: Al Ichwan, 1382/1962).

${ }^{64}$ Lihat Abdul Halim Hasan, Tafsir Al-Ahkam (Jakarta: Prenada, 2006).

${ }^{65} \mathrm{Hamka}$, et al., Sinar Memantjar dari Mesjid (Medan: Al Ichwan, t.t.).

${ }^{6}$ Penulis tidak menemukan deskripsi tentang buku-buku di atas. 